\title{
MARKET MANIPULATION AND THE EXCHANGE ACT
}

\author{
James War. Moore* and Frank M. Wisemanj
}

\section{THE MARKET CONCEPT}

$I^{1}$ $T$ was inevitable that some type of measure should be taken to correct the evils of over-speculation ${ }^{x}$ and financial racketeering ${ }^{2}$ occurring on organized security exchanges, and to prevent as far as possible another major stock market crash with its attendant grief and destruction. The Securities Exchange Act of $1934^{3}$ is the federal government's proffered solution. Since the aim of this paper is to examine the market concept under the Act, and that concept of a free and open market previously developed, no detailed analysis of the measure will be attempted. Its principal objectives are: (I) to curb excessive speculation; (2) to give the public adequate financial information concerning the securities traded in; and (3) to prevent illegitimate manipulation of security prices and protect the public against unfair practices. To effect these, the Act enunciates certain

* Sterling Fellow, Yale University School of Law.

$\dagger$ Member of the Ohio Bar.

I Loans to brokers on the New York Stock Exchange alone reached the unprecedented total of about $\$ 9,000, \infty 00,000$ at the peak of the bull market. The period between January I, I927 and October I, I929 accounted for an increase of $\$ 5,300,000,000$. Loans declined $\$ 3,000,-$ $\infty \infty,, \infty \infty$ in the first ten days of the debacle, and continued to decline for the next three years. These loans indicate the extent of stock market speculation. Feverish activity in trading is another indication. In the ten years before the war the yearly transactions in stock on the New York Stock Exchange averaged about $x 55,000,000$ shares; in I929 the volume had reached $I, I 25,000,000$ shares; and in I933, despite the depression, 654,000,000 shares were traded in. Twentieth Century Fund, Stock Market Control (r934), c. I and c. 6 at 86-95; 78 Cong. Rec. 7992-7993 (x934).

The extent to which inflation had gone and the consequent deflation when the bull market broke may be gathered in part from the following figures: in I929 the total value of stocks listed solely on the New York Stock Exchange was nearly $\$ 89, \infty 00, \infty 00,000$; in $x 932$ it had shrunk to less than $\$ r 6, \infty \infty 0,000, \infty \infty$; bonds on the same exchange had declined from $\$ 49, \infty 00$,$\infty 00,000$ in September, I930 to $\$ 3 \mp, 000,000,000$ in April, 1933. An extreme case of deflation is the decline in Insull Utilities Investment, Inc., from a high of approximately $S_{4} 49$ to $\frac{1}{8}$ of a point in I932. Twentieth Century Fund, Stock Market Control (r934) 7; 78 Cong. Rec. 7992, 840I (r934).

2 See generally the reports of the proceedings before the Senate Committee on Banking and Currency investigating stock exchange and banking practices published in r933 and I934.

3 P.L. No. 291, 73d (2d sess. 1934); I5 U.S.C.A. $\$ 78 \mathrm{a}$ (1934). See Tracy and MacChesney, The Securities Exchange Act of 1934, 32 Mich. L. Rev. 1025 (1934); Meyer, The Securities Exchange Act of $x_{934}$ (1934). 
general policies and lays out the plan for regulation and control. And a most important part of this plan is the creation of the Securities and Exchange Commission ${ }^{4}$ and the grant to it of broad regulatory 5 and investigatory powers ${ }^{6}$ over security exchanges. One feature supplementing the

$4 \S 4$ of tit. I. $\S 2$ Io of tit. $\Pi$ of the Act, amending the Securities Act of 1933 , transfers the powers, duties and functions of the Federal Trade Commission under the Securities Act, to this Commission, thus centering in one body control over the issuance of, and the trading in, securities.

5 \& 23(a) gives the Commission power to make necessary rules and regulations for the execution of the functions vested in it by the Act. These cover in the main:

(I) Classification of issuers, securities, and exchanges. $\$ 23$ (a).

(2) Approval or denial of an exchange's application for registration. $\$ 6$. An exchange may be exempted from registration, when in the Commission's opinion, by reason of the limited volume of business done thereon, it is not practicable nor necessary to require registration. $\$ \$ 23(a), 5$.

(3) Approval or denial of an application by an issuer to have its security registered is first lodged with the exchange; but the Commission has supervisory control over such approval. $\$ \S I 2$, Ig(a)(2). No securities may be traded in on a registered exchange unless they are registered or exempted. $\S$ r2(a). Exempted securities are defined by $\S 3$ (I2). In general terms they are federal, state, and municipal obligations, and such other securities as the Commission may deem proper to exempt from the operation of the Act, either absolutely or on terms.

(4) Segregation and limitation of functions of members, brokers, and dealers, as it deems necessary or appropriate. $\S$ II.

(5) Over-the-counter markets. $\& I_{5}$.

(6) Proxy solicitation; and the giving of a proxy by a broker or dealer in respect to a registered security carried for the account of a customer. $\S \mathrm{x} 4$.

(7) Periodical and other reports by the issuer of a registered security for the purposes of furnishing adequate financial information on its current status. $\S$ I3.

(8) The nature of accounts and records to be kept, and the reports to be made, by exchanges, members, brokers and dealers. The Commission may make such examination of the accounts and records as it may deem necessary. $\S \mathrm{I} 7(\mathrm{a})$.

(9) May exempt such dealings by directors, officers and principal stockholders in the securities of their company as are not comprehended within the purpose of subsection of $\S 16(\mathrm{~b})$, which aims at preventing the unfair use of information by corporate insiders. See in connection, $\&$ I 6 (d).

(ro) To regulate trading on foreign securities exchanges so as to prevent the evasion of the Act. $\S 3$.

(II) To regulate the aggregate indebtedness of brokers, $\$ 8(\mathrm{~b})$, and the hypothecation by brokers of securities carried for the account of a customer, $\$ 8(\mathrm{c})$.

(12) Manipulative and deceptive devices. $\$ \S 9$, ro. Certain devices are absolutely prohibited by $\S 9$, while others are conditionally prohibited, i.e., the Commission may permit the use of certain manipulative practices subject to rules. $\$ \S 9$, I0. These are discussed in detail, infra at pp. 50-56.

$\S$ I9 gives the Commission power to suspend or withdraw the registration of a securities exchange, or of a security, and to suspend or expel a member or officer of an exchange for violation of the Act or of the rules and regulations made by the Commission. It also has the power to suspend trading in any security for a period not exceeding ro days, or with the approval of the President, to suspend all trading on any exchange for a period not exceeding 90 days. $\S I 9(a)(4)$. And it may effect such changes in the rules and practices of an exchange as it deems proper in the public interest in respect to certain enumerated matters. $\S \mathrm{Ig}_{9}(\mathrm{~b})$.

$6 \S 2 I$. 
Commission should be noticed. The Act attempts to co-ordinate honest dealing on the exchanges with a controlled credit by setting up certain margin requirements ${ }^{7}$ and restrictions on borrowing by members, brokers and dealers; ${ }^{8}$ and by turning the regulation of this field over to the Federal Reserve Board.9

It is with objectives (2) and (3) that we are chiefly concerned. Now the original primary design of the stock markets was to secure liquidity for corporate and municipal securities. ${ }^{\mathrm{x}}$ That this function has been performed is attested by common experience during the last few years, for holders of securities traded in on national exchanges have been able to liquidate their holdings at all times, while holders of other securities have often found them frozen. This in itself is a considerable tribute to the mechanism of the exchange. But over-emphasis of this feature is dangerous, for transactions on the exchange affect not only the securities there handled, but serve as a yardstick to measure the tremendous immobile holdings of like securities throughout the country. ${ }^{\text {II }}$ Proper attention to pricing is therefore essential. Before market quotations can be accepted as an accurate appraisal of a security, the market must be free and open, both in the sense of liquidity - the continuous operations of buyers and sellers, and in the sense that price is honestly chancered. To effect the latter, buyers and sellers must have adequate financial information ${ }^{12}$ and the opportunity to trade on an unigged market. A great many businesses, probably the more intelligently managed, and the New York Stock Ex-

$7 \S 7$.

$8 \S 8$.

$9 \S 7$. See also $\S 23$ (a) giving it power to make rules and regulations; $\S>7$ (b) broker, dealer or other person extending credit must make such reports to the Board as it may require; and the Board is given power to examine accounts and records. For power to make investigations see $\S 8$ (a) providing: “ .... The provisions of sections 2 r (Investigations; Injunctions and Prosecution of Offenses) and 25 (Court Review of Orders) of this title shall apply in the case of any such proceeding or order of the Federal Reserve Board in the same manner as such provisions apply in the case of proceedings and orders of the Commission."

so Berle and Means, The Modern Corporation and Private Property (I932), c. I, bk. III. At an early date the New York Stock Exchange set up means whereby corners could be broken. Constitution of the New York Stock Exchange, Art IIII \& 7.

xr Berle and Means, supra note Io, p. 297.

22 In appraising values, information is needed on at least general business conditions; the condition of the industry involving the particular security; the financial record of the company and perhaps of other like companies for comparative purposes; and the demand for, and the resulting price of, the security. Government agencies such as the Department of Commerce and the Federal Reserve Board supply a great deal of information on general business conditions and specific industries. Clearly a company is the logical source of information concerning its financial status, and when it gathers its capital from the investing public, it would seem to have the duty toward this public of furnishing adequate information, not only at the time of issue but also currently. The basis for demanding current information is that the listing on a 
change ${ }^{\mathrm{x}_{3}}$ have heretofore recognized the need for such information. But in the past traders have not been adequately informed by the companies in whose securities they were dealing. ${ }^{14}$ Section I2 of the Exchange Act requires detailed information to be furnished at the time the security is registered, and section I3 requires the issuers of registered securities to keep the information filed under section 12 reasonably up to date. ${ }^{15}$

For the purpose of putting all traders on a fair basis, section $\mathrm{I} 6$ is designed to prevent corporate insiders from profiting from inside information, and sections 9 and Io prohibit manipulative and deceptive devices. Section I6(a) requires directors and officers of the issuer of a registered equity security (other than an exempted security), and holders of more

stock exchange was one of the factors giving the security salability at the time of issue; purchasers of the security were willing to and did pay more for the stock because they knew that at all times they could sell. To sell at a fair price, other purchasers must know the financial status of the company.

${ }^{{ }_{3}}$ An executive assistant of the committee on stock listing said: ". . . . In order that parties may trade on even terms they should have, as far as is practicable, the same opportunities for knowledge in regard to the subject matter of the trade.

"The exchange is interested in the accounts of companies as a source of reliable information for those who deal in stocks. It is not sufficient for the stock exchange that the accounts should be in conformity with law or even that they should be conservative; the stock exchange desires that they should be fully and fairly informative." H.R. Rep. No. 1383 , 73d (2d sess. I934); 78 Cong. Rec. 79I9-7920 (1934).

The information required by the New York Stock Exchange for listing has been detailed and thorough. See Commerce Clearing House, Stocks and Bonds Law Service (I933), Vol. III, 8237, et seq.; for comparative purposes see the requirements of other exchanges, p. 8023 et seg.

${ }_{54}$ "The majority of corporations make public no data whatsoever to inform their security holders of the (method of computing net) profits. . . . . There is absolutely no means by which the facts can be determined. . . . " Sloan, Corporate Profits (1930), 4I-43. Figures upon annual net earnings are published, of course; and what he means is that insufficient information is given regarding what such figures include and what they omit to enable a person outside the executive offices of the particular corporation accurately to determine the net profits.

That companies have not furnished sufficient information was admitted by the president of the New York Stock Exchange who advanced this explanation:

"6... however, many company officials did not publish complete financial statements because they were afraid that the disclosure of too much information would put their companies at a disadvantage in meeting competition, not only from other American corporations, but frequently from foreign companies engaged in the same line of business. This fear, though genuine, has in large measure proved to be unfounded." H.R. Rep. No. 1383 , 73d Cong. (2d sess. 1934), 78 Cong. Rec. 7919-7920 (1934). Protection against such danger is afforded by the Exchange Act. § 24 .

${ }^{25}$ Any person making a false or misleading statement with respect to a material fact in any application, report or document filed pursuant to the Act or rule of the Commission or Board is liable to any one relying upon it (not knowing that it was false or misleading) who sells or purchases a security at a price affected by the statement. The defendant may prove as a defense that he acted in good faith and had no knowledge that the statement was false or misleading. $\delta$ I8(a). In connection, see $\$ 20(a)$ which provides for liability of controlling persons. 
than 10\% of any class of unexempted equity securities to file with the Commission at the time of registration a list of their holdings of the issuer and to supplement this with monthly reports when there has been any change in such ownership. This is to give investors an idea of the purchases and sales by corporate insiders. And section $I 6(\mathrm{~b})$ provides that profits accruing from deals by such individuals (with certain exceptions not here material), in the issuer's securities within a period of six months shall enure to the benefit of the issuer; and section $\mathrm{r} 6(\mathrm{c})$ is designed to prevent short sales by the above individuals when dealing in registered securities of their company, and to prevent sale for delivery after twenty days - to prevent sales against the box, whereby those in possession of inside information sell their holdings but keep the stock registered in their names, so that their change of position does not become known until delivery is made at a later date.

In discussing sections 9 and Io on manipulation it may be well to refer to devices that have been employed in the past and for what purposes. The term "manipulation" may, in short, be applied to any practice which has as its purpose the deliberate raising, lowering or pegging of security prices. Buying and selling in themselves do, of course, affect price, but in a free and open market this is a natural consequence and not their preconceived purpose. Manipulation leads to an artificial and controlled ${ }^{16}$ price. Such a price, which is broadcast in the form of a market quotation, then, does not reflect an independent appraisal of the security in respect to the floating supply, nor to the immobile holdings throughout the country. ${ }^{17}$

A crude form of creating a false appearance of demand and market price for the benefit of the ticker is the wash sale ${ }^{\mathrm{x} 8}$ and matched order. ${ }^{19}$ These are prohibited by section 9 (a)(r) of the Act. For some time the New York Stock Exchange has condemned such transactions; ${ }^{20}$ the New York Blue Sky Law, known as the Martin Act, designates them as fraudu-

${ }^{16}$ The degree of control depends upon success of the manipulation; but control is the aim and hope of the manipulator.

${ }_{17}$ Where a syndicate controls the market, the market quotations are not determinative of value for tax purposes. Appeal of Wallis Tractor Co., 3 B.T.A. 98x (r926); Parker v. Commissioner, II B.T.A. I336 (r928).

${ }^{18} \mathrm{~A}$ sale involving no change in the beneficial ownership; the seller does not expect to make, nor the buyer to receive, delivery.

I9 An order for the purchase or sale of a security given for substantially the same size, at substantially the same time and at substantially the same price at which the party is making a sale or purchase. The party trades with himself, or with someone acting in concert with him. Quite generally the term wash sale is used also to cover matched order.

${ }^{20}$ Constitution of the N.Y. Stock Exchange, Art. XVII, §3. 
lent and provides for action of a preventive nature by the AttorneyGeneral; ${ }^{2 x}$ and the state penal code designates them as felonies. ${ }^{22}$ Other effective manipulative devices, and just as reprehensible, are the rumor, false statements and touting ${ }^{23}$ relative to a security. These are prohibited by section $9(a)(3),(4)$ and (5). ${ }^{24}$ Another manipulative device, generally assumed to be legitimate, ${ }^{25}$ is the pool operation. Its purpose is, by concerted action among a number of traders, to raise or lower or maintain the price of a security at a certain level. In so far as this purpose is achieved, an artificial price results; that is, a price which would not be reached by the competing judgments of independent buyers and sellers. Even where the pool in the end suffers financial loss it disaligns price appraisal ${ }^{26}$ during the period of operation.

Pool operations fall into two general classes: (I) those designed to serve merely speculative purposes in the endeavor to make a profit as the result of fluctuations planned in advance-the bull and bear pools; ${ }^{27}$ and (2)

${ }^{2 x}$ New York Cahill's Consolidated Laws (I930), c. 2I, $\$ \S 35^{2}-359-J$, Art. 23-A of the General Business Law.

${ }_{22}^{2}$ New York Cahill's Consolidated Laws (I930), c. 4r, $\$ 953$.

$\$ 95^{1}$ makes reporting or publishing of fictitious transactions in securities a felony.

${ }^{23}$ The two most common forms which touting takes seem to be $(I)$ the sending out of circular letters containing market information and advice, allegedly expert and impartial, but which are in reality dedicated to the unloading of certain securities, and (2) the dissemination of the same sort of stuff through financial papers and sheets. For examples of such practices unearthed by the Senate Committee on Banking and Finance, see II, Stock Exchange Practices, 73d Cong., Ist sess. (I934), 459 et seq; 600 et seq. See generally Twentieth Century Fund, Stock Market Control (I934), c. VII.

New York Cahill's Consolidated Laws (I930), c. 4 r, $\S 95^{2}$ makes false statement or advertisement as to securities a felony.

${ }^{24}$ See infra note 85 for similar state prohibitions.

${ }_{25}$ Meyer, The Law of Stock Brokers and Stock Exchanges (I93I), 240, § 36 .

${ }^{26} \mathrm{It}$ is price appraisal which an apologist for stock exchanges has emphasized as their most valuable contribution. Through reports of transactions and resulting prices the public is informed by the market quotation of the combined opinion of the most competent financiers as to the present and future value of securities. "When the facts (which affect value) become the common property of the rank and file . . . . , their effect is lost because the discerning mind of the speculative community has approximately measured their importance in advance and by its sales and purchases has brought about a prompt adjustment of the price to a lower or higher level." Huebner, Stock Market (rg22), 33.

27 A bear pool is a combination to sell a security short and then buy at the depressed prices. While on the other hand a bull pool is to first acquire stock and then unload at a marked-up price.

The sucker pool is a combination of large holders of stock, who anticipating a decline desire to unload profitably. Invitations will be sent out over the country to small brokers requesting them to take a share; enthusiasm is spread among the invitees and they are properly made to feel the favor being done them. The buying by them and their customers keep or push the price up to levels where the large holders can unload profitably. Dice, The Stock Market (I926), 428 . 
those resorted to for the purpose of making a market for issues of new securities or stabilizing the price of a seasoned security subject to stress of unusual circumstances-the syndicate distribution pool $^{28}$ and the stabilization pool. ${ }^{29}$

Economic justification for pools of the first class has been attempted. "The pool is thus little more than an organization, on a scientific basis, of

${ }^{28}$ The aim of the investment banker who manages the syndicate distribution pool is to maintain the offering price to the public at a time when the security is coming on the market in large volume with a varying demand. Thus the market in which he operates is a forced market. For example, a large utility needing capital goes to its investment banker. After a careful study of its needs, its property, past and future earnings, the general condition of the security market, and other kindred fields the banker contracts to purchase from the issuer $\$ 25, \infty 00, \infty 00$ six per cent mortgage bonds to yield the issuer go. The banker takes a $\frac{1}{2}$ point for origination and makes the price go 2 to the banking group which he forms and of which he is a member. (The purpose of this group is to underwrite his risk.) A selling group of $35^{\circ}$ houses, scattered all over the country, is formed to take commitments for sale, price to members of the selling group 9I, offering price to the public 93. The originating banker will participate and manage the selling group. These various syndicates are formed for periods approximating sixty days, and the managers usually reserve the right to extend the period. (See the case of Fisher, Lawrence and Bowen in Biddle and Bates, Investment Banking [r93x], 235.) During the life of the syndicate it will bid on the market for bonds at 93, unless its appraisal of the market has been so poor that it is unable to support the market at that price-if the investing public which has purchased bonds becomes convinced that 93 is too high, bonds will appear on the market for sale, and if 93 is far out of line, so many bonds will come upon the market that the syndicate will be unable to support the market at that figure. See the case of Fabre, Dupont \& Co., Inc., in Biddle and Bates, Investment Banking ( $193 \mathrm{I}$ ), 267, where the banker was marketing bonds and a large block of preferred stock. The total issue of the latter was $\$ 35,000, \infty 00 ;$; $11, \infty 00,000$ had been exchanged by the isuing company for securities of subsidiary companies, and the banker undertook to market the balance of $\$ 24,000,000$ million. Bonds, preferred stock, and common stock were pegged. Assuming that the pegging of the new security is justifiable can the same be said in regard to pegging the common stock which is already on the market, or in pegging the preferred with \$II,000,000 outstanding? In this case seemingly the outstanding preferred had not been traded in; so the entire block of preferred stock can be treated as a new security and pegging would seem to be justifiable if we so regard it in such a situation as Fisher, Lawrence and Bowen. If the outstanding preferred had been traded in, then the pegging interferes with free trading in a seasoned stock, yet since the same type of stock is coming on the market in large volume, the stress of circumstances requires support just as much as in the marketing of a new security. See infra note 29.

29 The Bond Pool formed in 1932 and publicly announced as designed to support the market, easing the effects of panic hysteria, is an example. It was generally thought to be in the public interest. See the N.Y. Times, Oct. 27, I929, pp. I, I6 for an account of the bankers' syndicate which operated in the crash of 1929 to prevent the collapse of issues under which "pockets" had opened through the complete absence of bids to stem a torrent of sales. And see Berle, Liability for Stock Manipulation, 3I Col. L. Rev. 264, 278, n. 25 (I93I) and cf. the less drastic method outlined in n. 26 of the same article.

A less spectacular use of the stabilization pool is to cushion seasoned stock during the marketing of a large block by a holder. For example, to close up the estate of $A$, it is necessary to sell his large security holdings in X stock. Support here may prevent undue injury both to the estate and the public who have holdings in X stock. Cf. the case of Fabre, Dupont \& Co., Inc. supra note 28. 
a group of 'insiders.' It is a group of men who are farsighted enough to see the potentiality of any stock and the logic of its eventually selling at the price and in the direction which the pool decides upon. All that the pool generally does, therefore, is to discount the future in a scientific way and hasten the market change which, without organized action, might take ten times as long to accomplish. Economically, the pool serves a worthy purpose of assisting the open market in evaluating correctly the true worth of a stock." ${ }^{30}$ But this justification seems addressed to a market where there are "insiders," not to a free and open public market. Granting that there may be good pools if they mark up or mark down stock to what, in theory, is the proper level, there are sufficient examples of security values so grossly disaligned that such evils far outweigh any possible good from such theoretic appraisal. ${ }^{3 x}$ For it is believed that sound appraisal will normally characterize a free market, unless the forces of over-speculation, such as we witnessed in I928 and 1929 , or the opposite forces of fear and depression of the late years disrupt the mechanisms of orderly trade. But when those forces are at work the pool usually accentuates them, since it is much easier for it to go with than against the general trend of the market. ${ }^{32}$

${ }^{30}$ Schabacker, Stock Market Theory and Practice (I930), 570-57I; and see Meeker, Short Selling (1932), 83 .

${ }^{3 x}$ Hocking Pool, 1909: Stock earning one-half of one per cent was forced up from \$24 to $\$ 92.50$ per share; entire number of shares listed was 69,304 , yet in March when pool operations began, I43,400 shares were traded in; upon the termination of the pool the stock declined to $\$ 2$ per share and then disappeared. U.S. Senate Hearings, Regulation of the Stock Exchange, 63 d Cong. 2d sess. on S. 3895 (IgI4), 94, Pujo Report, 47-49.

Radio Pool, I929: The common stock of Radio Corporation of America was pushed up from a close of $91 \frac{3}{4}$ on March I2, I929 when the pool began operating, to a close of Iog 2 on March I6, receding on March I8 to a close of xor, and on March I9 to $96 \frac{1}{8}$ when the last holdings had been unloaded. Thereafter the stock declined for several days to a closing price of $87 \frac{1}{4}$ on March 23. The pool operated for only one week, yet traded in $I, 493,400$ shares at a net profit of nearly $\$ 5, \infty 00,000$. II Stock Exchange Practices (73d Cong. Ist sess.), 473-475, Letter from the Counsel for the Committee on Banking and Currency to the Committee on Banking and Currency (73d Cong. Ist sess.), 9. The prices quoted are the corrected prices found in the Letter.

Alcohol Pool, I933: see infra note Ioo.

And see Vol. II, op. cit., supra, at p. 559, Letter, op. cit., supra, at p. I2 for an account of the Kolster Radio Pool which operated under an option to purchase, as did the pool in Electric Auto-Lite Company (Vol. II, at p. 750, Letter, at p. 18). In the General Asphalt Pool officers and directors of the company were interested. Thus the pool had knowledge of what the company intended to do with respect to declaration of dividends, and the evidence that dividends were paid in amount and at a time to assist the pool in its maneuvers and to the detriment of the company is impelling. Vol. II, 532-546, Letter, II-I2. For an extreme example of exploiting inside information, and manipulation, see the résumé relative to Fox Theaters and Fox Films, Letter, $26-32$; and see also the resume on Warner Bros. Pictures, Letter, I8. (No attempt is made to refer to all the pool operations unearthed by the Senate Committee Investigation.)

32 Publicizing the fact that a pool is operating in a security sometime serves as stimulant to lure speculators into the market. See Stevens v. Wallace, I06 N.J. Eq. 352, I 50 Atl. 835 (I930) 
A much better case can be made for pool operations of the second class. In those of the first class the greater price fluctuation produced, the greater the profit. While in the syndicate distribution, the underlying theory is that the investment banker and his associates must create an orderly market which will permit them to purchase securities to yield a fair price to the issuer and market these wares at a profit commensurate with the risk taken. ${ }^{33}$ This interference with a free market has been justified ${ }^{34}$ and attacked. ${ }^{35}$ Essentially the problem is one of pricing, and if the investment banker gives proper attention to the buying public's point of view a price fair to all is more apt to result from orderly, controlled marketing than in a free and open market where the supply for the time far exceeds the demand. There is considerable evidence that in the past the investment banker has unduly considered the interests of the issuer. ${ }^{36}$ And this has led to the suggestion that American investment bankers by adopting the English practice need not resort to pegging. ${ }^{37}$ In England many companies make the offering of their own securities direct to the public. This indicates that they are content to wait longer for the proceeds of their issue and to assume the risk of getting the amount of funds desired. Where the investment banker is used either to insure the sale of the issue, or to undertake its marketing, the tempo is still much slower than in America. But aside from this there is probably no real difference, for jobbers are em-

(the manipulator advertised that a pool was operating); and see the Dickinson Report to Secretary of Commerce of Committee on Stock Exchange Regulation (1934), ז4; I38 Commercial and Financial Chronical 925 (r934).

33 Where the originating house was able to set up the syndicate machinery and secure commitments for the entire issue before it became formally committed to the issuer the risk taken was small, and the profit may have been disproportionate to the economic services rendered. Even where it became committed to the issuer before the risk was underwritten its profits may have been too large.

34 Report of the Governor's Committee (of N.Y.) on Speculation in Securities and Commodities (I 109 ) as quoted in Appendix K, p. $80 I$ of the Regulation of the Stock Exchange, U.S. Senate Hearings, 63 d Cong., 2 d sess. on S. 3895 (rgr4); Dickinson Report to Secretary of Commerce of Committee on Stock Exchange Regulation (I934), I3-r4.

35 Twentieth Century Fund, Stock Market Control (1934), I93.

${ }^{36}$ Steiner and Lasdon, The Market Action of New Issues-A Test of Syndicate Price Pegging, I2 Harv. Bus. Rev. 339 (I934); Twentieth Century Fund, Stock Market Control (I934), I94.

The writers examined 63 issues sponsored by the firm of J. P. Morgan \& Co. during the years 1927 to 1930 , inclusive. Ten issues did not break the offering price; pricing was particularly bad on four issues; on the other issues it was reasonably close. The survey tended to prove that the best class of investment bankers probably priced their wares reasonably, even from the purchaser's point of view.

37 Twentieth Century Fund, Stock Market Control (1934), I94. 
ployed both by companies when marketing their own securities, ${ }^{38}$ and by the investment bankers to make a market on the exchanges in the security. ${ }^{39}$ So even if a shift were made in this country in investment banking practices and a company went directly to the public, it has been recognized that it would have to lend support to the market if it were to be successful in its financing..$^{40}$

The theory which justifies pegging justifies stabilizing a seasoned security to aid in the orderly liquidation of a block of securities, which, if thrown upon the market without support, would demoralize and depress it to the disadvantage of the liquidator and to the public having holdings in that security. It has been urged that such securities could be fed out slowly, but creditors, and unusual circumstances, such as settling an estate, may demand sudden liquidation. ${ }^{4 \mathrm{x}}$ And where a security is subject to unusual strain, as panic hysteria, stabilization may well be resorted to for the purpose of protecting the public generally, and preventing undue sacrifice in values. ${ }^{42}$

That pool operations divide into the legitimate and illegitimate is recognized by the Exchange Act. Section $9(a)(2)$ prohibits speculative pool operations and operations by the lone trader which raise or depress the price of a security "for the purpose of inducing the purchase or sale of such security by others." While section $9(a)(6)$ only prohibits pegging, fixing, or stabilizing the price of a security by the lone trader or traders acting in concert when "in contravention of such rules and regulations as the Commission may prescribe." The put, ${ }^{43}$ call, ${ }^{44}$ straddle, ${ }^{45}$ and other kindred options and privileges, often concomitants of pool operations be-

${ }^{8} \mathrm{Sec}$ the cases of Scott v. Brown, infra, note 56 , and Sanderson and Levi v. British Westralian Mines and Share Corp., infra, note 6o. In both cases the court recognizes the practice is common.

39 Nash, Investment Banking In England (I924), 60; and see generally c.c. IV and V, and particularly the chart on p. 86 .

40 Dickinson Report to Secretary of Commerce of Committee on Stock Exchange Regulation (1934), r4.

4 Ibid. I4. 42 Ibid. I4.

43 "A put is an option in favor of the holder of the put to require the maker to purchase and pay for specified stock at any time within a specified period." Meyer, The Law of Stock Brokers and Stock Exchanges (x931), §31.

${ }_{44}$ "A call is an option in favor of the holder of the call to require the maker to sell and deliver specified stock at any time within a specified period." Meyer, supra note $43, \S 3 \mathbf{r}$.

${ }_{45}$ "A straddle or a spread is a combination of a put and a call. It grants the holder the right to require the maker, within a named time, either to purchase at a specified price or to scll at a specified price. The difference between a straddle and a spread is that in a straddle the price is the same in the option to purchase as in the option to sell, (this price usually being the market 
cause they permit large-scale manipulations to be conducted with a minimum of financial risk to the manipulators, ${ }^{46}$ are made unlawful save when they are permitted by the Commission's rules and regulations. ${ }^{47}$ And any person willfully participating ${ }^{48}$ in any act or transaction in violation of the specific prohibitions of this section ${ }^{49}$ or the rules and regulations of the Commission made thereunder is liable to any person purchasing or selling any security at a price which was affected by such act or transaction. ${ }^{\circ}$ To effect a short sale or to use a stop-loss order in connection with a registered security in contravention of the Commission's rules is prohibited by section Io(a). And section ro(b) prohibits the use of any manipulative or deceptive device in connection with the purchase or sale of any security registered on a national securities exchange or any security not so registered in contravention of the Commission's rules and regulations.

Thus it seems the Act seeks to establish a free and open market, yet recognizing that complete freedom may be demoralizing, qualifies the concept by delimiting speculation and by authorizing such legitimate manipulation as the Commission thinks necessary or appropriate in the public interest or for the protection of investors. How does this concept differ from that prevailing prior to the Act? The answer to this question is important both to provide a setting for the Act, and to determine if other rights and remedies are available, because section 28 makes the rights and remedies under the Act supplementary to any that may exist at law or in equity..$^{5}$ Let us then examine the English and American cases which bear upon the concept of a free and open market.

price at the time the straddle is executed), whereas in a spread the prices at which the two options may be exercised are different." Meyer, supra note $43, \S 3$ r. The put, call, straddle. spread and such options are legal. Meyer, supra note $43, \S 34$ (f).

${ }_{45}^{6}$ H.R. Rep. No. 1383, 73d Cong., 2d sess. (1934); 78 Cong. Rec. 7919 (1934); Meyer, op. cit., supre $\$ 3 I$.

$47 \S 9$ (b) and (c). The terms do not include any registered warrant, right, or convertible security. $\S 9$ (d).

${ }^{48}$ See also $\$ 20$ which makes controlling persons liable also.

49 In addition to matters under immediate discussion $\$ 9$ prohibits fictitious transactions, circulation of false rumors, the making of false and misleading statements, and touting, discussed supra p. 5 r.

${ }^{50} \S g(e)$. This subdivision provides for protection against strike suits. $\S 9$ does not apply to an exempted security. $\S 9(\mathrm{f})$.

${ }^{5}$ This is subject to the proviso that any person permitted to maintain a suit for damages under the Act cannot, through satisfaction of judgment in one or more actions, recover in excess of his actual damages. $\S 28$ (a). This subdivision also specifically preserves the validity of state blue sky laws not in conflict with the Act.

$\$ 28$ (b) leaves the exchanges free to regulate themselves and their members insofar as the action taken is not inconsistent with the provisions of the Act. In this connection $\S 6(\mathrm{~b})$ should 


\section{ENGLISH CASES}

Two criminal cases clearly recognize the public interest in a free and open securities market. In the first case to arise ${ }^{52}$ the defendants had circulated false rumors to the effect that Napoleon had been killed and peace would soon be proclaimed. Charged with and convicted of a conspiracy to raise the price of the public Government funds and other Government securities by the above false means with the intent to injure the public who should buy such securities on a named day, they moved in arrest of judgment, urging that generally speaking the higher the price of the public funds the better for the country because the higher the state of public credit; that it was not alleged that defendants had shares in the funds and intended to sell them; nor that the Government would be injured, as it might if the particular day were the one on which the Commissioners for Reducing the National Debt were wont to purchase. But a unanimous court overruled these objections, recognizing that the Government need not be injured in its aggregate capacity ${ }^{53}$ nor that the defendants be benefited. Both the means used and the end sought were illegal: the public had a right that a national market should not be tampered with..$^{54}$ The interesting question whether a combination to sell or buy in large amounts for the sole purpose of depressing or raising the price of stocks would be indictable was not discussed..$^{55}$ But there are dicta to the effect that such a combination would be criminal..$^{6}$ These must be deemed qualified,

be noted. It provides that a registered exchange must provide "for the expulsion, suspension, or disciplining of a member for conduct or proceeding inconsistent with just and equitable principles of trade, and declare that the willful violation of any provisions of this title or any rule or regulation thereunder shall be considered conduct or proceeding inconsistent with just and equitable principles of trade."

52 Rex v. De Berenger, 3 M. \& S. 67, 105 Eng. Rep. 536 (K.B. I8I4).

53 Bayley, J., id., 75, 539, "To raise the public funds may be an innocent act, but to conspire to raise them by illegal means and with a criminal view, is an offence; an offence, perhaps not affecting the public in an equal degree, as if it were done with intent to affect the purchases of the Commissioners for the Redemption of the National Debt, which would be affecting the public in its aggregate capacity; but still, if it be completed, it will certainly prejudice a large portion of the King's subjects who have occasion to purchase on that day."

54 Lord Ellenborough, C. J., id., 72-73, 538, ". . . The purpose itself is mischievous, it strikes at the price of a vendible commodity in the market, and if it gives it a fictitious price, by means of false rumours, it is a fraud levelled against all the public, for it is against all such as may possibly have anything to do with the funds on that particular day."

ss However, Le Blanc, J., did point out that raising or lowering the price of securities is not per se a crime, but explained that by saying, "A man may have occasion to sell out a large sum, which may have the effect of depressing the price of stocks, or may buy in a large sum, and thereby raise the price on a particular day, and yet he will be guilty of no offence." Id., 74, 539 .

${ }^{5}$ Scott v. Brown, [I892] 2 Q.B. 724, 730, 734, 6I L.J. $73^{8}$ (Q.B. I892). 
however, to the extent that if the resulting price is fair, though at a premium, the combination is not indictable..$^{57}$

And the English law has taken a very objective view concerning intent. In Reg. v. Aspinall ${ }^{58}$ the defendants by fictitious allotments, and by false representations concerning these and the amount that had been paid thereon secured a settling day on the London Stock Exchange. The second count, on which the conviction was sustained, charged a conspiracy to falsely obtain a listing of the stock for the purpose of inducing traders to believe that the rules of the exchange had been complied with. There was no allegation that the purpose, for which that belief was sought to be produced in the minds of traders, was to injure them by inducing them to buy shares which were either valueless or, at all events, inferior in value to what they appeared to be. Also, the defendants were found not guilty upon the last count which averred an intent to defraud the public of money. The case would seem to stand for the proposition that although the subjective intent toward the public is honest, the false listing is a tampering with a public market which inevitably harms third persons and is therefore criminal. 59

It is plain from these cases that the public has an interest in security markets which it can protect by proper criminal proceedings. And in cases between market manipulators the courts have recognized the free and open market concept. Pegging the market during either primary or secondary distribution is legal and a contract to effect such a purpose is enforceable, provided the price at which the security is pegged is a fair price to the public $;^{60}$ but if the price is such that a court will regard it as fictitious, a sham and a fraud upon the public, the court will not lend its aid to enforcement but will raise the matter of illegality on its own mo-

57 Sanderson and Levi v. The British Westralian Mines and Share Corporation, 43 Sol. J. 45 (I898), affd. sub nom. Sanderson and Levi v. British Mercantile Marine \& Share Co., Ltd., London Times, July I9, I899, also reprinted in U.S. v. Brown, 5 F. Supp. 8I, at p. 90 (I933).

${ }^{8}$ I Q.B.D. $73^{\circ}$ ( 1876 ), affd. in 2 Q.B.D. 48 ( 1876 ).

59 "It was objected that the Court could not take judicial notice that a non-compliance with the rules set out in the count would, if known, depreciate the price of shares ... . They are ... . in these days bound to take notice that shares in limited companies are a vendible com. modity; and that a purchaser of ordinary intelligence would prefer to purchase shares in a limited company which had fulfilled the requirements of rule 128 (the Stock Exchange rule on allotments and payment in part of subscription price), rather than in the same company when it had not fulfilled those requirements." Brett, J.A., 2 Q.B.D. 48, 6r-62 (I876).

"That omission (to allege design to injure and deceive purchasers), however, appears to be immaterial, if the natural and probable effect of deceiving the committee in the mode alleged would be to injure and deceive purchasers." Amphlett, J. A., 2 Q.B.D. 48, 64-65(1876).

${ }^{60}$ Sanderson and Levi v. The British Westralian Mines and Share Corporation, supra note 57 . 
tion. $^{6 x}$ A fortiori, contracts for speculative pool operations where the purpose is solely to mark up or mark down prices to the profit of the contractors, being without sufficient economic justification, would be illegal and void.

There are dicta in Scott v. Browm ${ }^{62}$ that any third person induced to purchase from the contractors at the unfair price may sue either or all of them. But where third persons have sought to hold a market manipulator in a tort action for damages sustained, the courts have either refused to hurdle the barrier of remote injury, or have been bogged by the tortious character of a deceit action or an action in the nature of conspiracy. In Bedford v. Bagshaw ${ }^{63}$ the defendant and others forming the board of management of a joint stock company, effected a listing on the stock exchange of the shares of the company, by falsely representing that two-thirds of the scrip had been paid upon. The plaintiff, knowing the requirements of the stock exchange, purchased $£_{I}$ shares on the exchange from third persons for ros., thinking that although the company would probably prove unsuccessful it would, nevertheless, liquidate at $I_{5} \mathrm{~s}$. to his profit. The shares turned out to be valueless, and it was held in the Court of Exchequer that the defendant was liable in an action of deceit to the plaintiff for the damages sustained. But Lord Chelmsford expressly overruled this case in Peek v. Gurney. ${ }^{6}$ Possibly he need not have disturbed that case. ${ }^{65}$ It might be argued that the object of the false statement in the Bagshare case was to use the stock exchange as a conduit to give marketability to the shares, i.e., the ultimate object was to influence third parties gener-

${ }^{6 r}$ Scott $\mathrm{v}$. Brown, sulpra note 56 . The action of the brokers in pegging the market was of such a character that the Stock Exchange characterized it as disgraceful and dishonorable and expelled them from membership. This may only mean that the Exchange felt that it was expedient to discipline someone in view of the Court's strong language in Scott v. Brown. See Brown v. The Committee of the Stock Exchange, 36 Sol. J. 752 (x892).

${ }^{62}$ Supra note 56 , at p. 734 .

${ }^{6}{ }_{4}$ H. \& N. 538, ${ }_{57}$ Eng. Rep. 95 r (r859).

${ }_{6} 4$ L.R. 6 H.L. 377 (I873). Defendants, directors of the A. Co., issued a prospectus containing false representations, on which plaintiff relied, purchasing shares. He was not an original allottee, however. The A Co. failed and plaintiff was made liable as a contributory. He brought a bill in equity seeking indemnity from the estates of the directors. Recovery was denied on the theory that the action was governed by the same law that would govern an action in fraud and deceit; that the false representations were made only to the original allottees - the function of the prospectus was fulfilled when the allotment was completed. For Lord Chelmsford's discussion of Bedford v. Bagshaw, see p. 396 et seq.

The English digests cite Bedford v. Bagshaw as overruled. But cf. Berle, Liability for Stock Manipulation, 3 r Col. L. Rev. 264, 269, n. 9 (I93I).

${ }_{65}$ For a statement by Day, J., that he thought the case of Peek v. Gurney might have been decided without any reference to Bedford v. Bagshaw see Salaman v. Warner, 64 L.T.R. N.S. 598,600 (Q.B.D. $\mathrm{x} 89 \mathrm{r}$ ). 
ally to regard the shares as having a certain basis which they did not have, while in the Gurney case the ultimate object of the prospectus was attained when a complete allotment was effected.

In Salaman v. Warner ${ }^{66}$ the plaintiff, a broker on the London Stock Exchange, sold short shares in a new company promoted by the defendants, and through a manipulative corner effected by them was obliged to pay prices far in excess of his selling price. The action was to recover the damages so sustained. He alleged that the prospectus which the defendants procured to be issued stated that two-thirds of the shares were bona fide offered to the public; that the defendants by false representations made to the directors were able to secure allotment of the bull of the shares to their nominees; and then to effect their original plan of making large profits from short sellers, the defendants went on and secured a settling day upon the exchange by making false representations to its governing board concerning bona fide allotment; that in reliance upon the above statement in the prospectus and in further reliance upon the rule of the exchange not to grant a settling day until two-thirds of the shares had been bona fide allotted, the plaintiff sold short a large number of shares (after defendants had secured false allotments); that he was obliged to carry out these contracts as a result of the appointment of the settling day, and because of the defendants' manipulations was obliged to pay exaggerated prices for the shares. The plaintiff proceeded on two theories: (I) an action of deceit which subdivided itself into two heads: first, an allegation of deceit leading to the contracts which the plaintiff entered into for the sale of shares which he did not possess; and secondly, an allegation of deceit which embarrassed and injured the plaintiff in the mode in which he carried those contracts into effect; (2) an action of conspiracy. (It was held that the statement of claim disclosed no cause of action. Since the plaintiff did not rely upon the prospectus and become an original allottee, he could predicate no loss on the false statement concerning the bona fide offer to the public, ${ }^{67}$ and there was no reliance upon the false representa-

${ }^{66} 64$ L.T.R. N.S. 598 (Q.B.D. 189 r), affd. by the Ct. of Appeal in 65 L.T.R. (N.S.) ${ }_{32}^{2}$, 7 T.L.R. 484 (C.A. I89r).

${ }^{67}$ See the opinion of Day, J., Salaman v. Warner 64 L.T.R. (N.S.) 598, 60I (Q.B.D. I89I), where he says: "It [the prospectus] did not lure him to subscribe for shares. It did not deceive him as to the merits of the company, for, so far from attaching any importance to the allegations which no doubt were contained in the prospectus as to the merits of the company, immediately on its publication, and almost before he had time to read it, he seems to have devoted himself to selling speculatively shares in the company."

It is very plain from his opinion that he regarded the plaintiff as a speculator trying to recoup his losses from an adversary that had outwitted him. He characterizes the litigants as 
tions to the directors inducing the allotments, for the plaintiff never learned of them until after he had sold short. Conceding all that, the plaintiff, nevertheless, contended that his contracts were only conditional and would never have become absolute to his damage had it not been for the deceit practiced upon the stock exchange inducing it to fix a settling day. ${ }^{68}$ The answer, viewing the Bagshaw case as overruled by the Gurney case, is that the injury is too remote. The theory of conspiracy was to the effect that wherever there is a conspiracy to do an unlawful act followed by the execution of an unlawful act, which injures a member of any class of the public with intent to injure whom the act was done, then a cause of action arises to every person so injured. This contention was disposed of by the proposition that a conspiracy in itself does not create a new civil right in the plaintiff. ${ }^{69}$ Thus, unless the court was prepared to hold that the plaintiff had a right that the defendant should not tamper with a national security market, no right had been invaded by the combination and there could be no recovery. The court apparently refused to recognize such a right. Lord Justice Fry said:

"In the case of Barry v. Croskey Lord Hatherley, then Vice-Chancellor, adverting to an argument of Mr. Rolt, said: 'Your argument would show that every person who, in consequence of De Berenger's frauds upon the Stock Exchange, was induced to purchase stock at an advanced price in reliance upon the false rumour he had circulated that peace was concluded was entitled to maintain an action against De Berenger for the increase of price. Would not such consequences be too remote to form ground for an action?' Now, it is evident that the Vice-Chancellor meant to say that they were too remote, and that Lord Cairns in citing it (in Peek v. Gurney) intended to adopt that view, and to hold that they were too remote. But then it is said . . . . that the learned Vice-Chancellor's proposition did not embrace this point, that the persons who were supposed to be bringing their actions were persons whom it was the intention of De Berenger and his fellow conspirators to injure; but it is obvious that these conspirators intended to injure those who bought from them by the fall of stock which would follow the discovery of the falsity of the rumour. The hypothetical plaintiffs referred to by the Vice-Chancellor were the persons whom the conspirators must have intended to injure, and without an injury to whom no benefit would have resulted to themselves. It follows, in my judgment, that it is too large a proposition to say that

two sets of people endeavoring to overreach one another, and states that the law will not make the successful one responsible to the other. But this overlooks the fact that a short seller sometimes performs a very useful economic function, and though he is a speculator he is entitled to trade on an unrigged market.

${ }^{68}$ Lord Justice Fry's handling of this contention is rather unsatisfactory. 65 L.T.R. (N.S.) I32, I35 (C.A. I89I).

${ }^{69}$ Hutchins v. Hutchins, 7 Hill (N.Y.) I04 (Sup. Ct. I845), reprinted in Bigelow, Law of Torts, Leading Cases ( 1875$), 207$, and see the note to the case, at 214 et seq.; Webb, Pollock on Torts ( 1894$), 401-402$. 
every person whom conspirators may intend to injure, and who are injured by the conspiracy, has an action against the conspirators."7o

But wherever a plaintiff has been able to bring himself within a contract or a relationship which the court was willing to treat as a trust he has been quite successful. Barry v. Croskey ${ }^{7 x}$ presented a factual set-up very much like that in the Warner case. The individual defendants were directors of the company, the secretary, a promoter, and a stock-jobber. Acting in concert they secured allotments to be made to themselves through fictitious persons and then entered into contracts of purchase from the plaintiff, a stock-jobber, and others similarly situated, through the defendant stock-jobber. Then through false representations they obtained a settling day upon the exchange. The plaintiff, not being able to obtain shares on that day, paid a sum to the defendant stock-jobber and secured an extension of time to the next regular settling day. Transactions resulting in payments and extensions were repeated several times until finally the plaintiff paid a certain sum and was released from his contract. Later he brought his bill in equity against the various individual defendants who had acted in concert and against the company whose shares had been dealt in, to recover the various sums paid by him to the defendant stock-jobber. It was held that his action would lie against all the individual defendants if his bill were amended to show that the various sums paid by him were paid before he discovered the manipulation practiced upon him. But his bill was dismissed as to the company on the theory that he had no contractual relationship with it, and assuming the company to be liable to proper parties for the false representations made by its directors to the stock exchange which effected the settling day, that the plaintiff's injury was too remote. ${ }^{72}$ But the principle of this case will not be applied to the injury of an innocent third party.73 And where the market

${ }^{70}$ An interesting comment by Lord Justice Rigby on Rex v. De Berenger, and on Lord Hatherley's and Lord Justice Fry's statements is to be found in Andrews v. Mockford, [1896] I Q.B. $372,384-385,73$ L.T.R. 726 , which held defendant promoters liable in deceit to a purchaser of shares on the Stock Exchange for false statements in the prospectus, coupled with a false telegram caused to be published in a financial paper for the purpose of supplementing the prospectus, thus inducing the public to buy the remaining shares-the original allotment not having been completely successful.

$7^{x} 2$ J. \& H. x, 7o Eng. Rep. 945 (x86r).

72 In Salaman v. Warner, supra note 66, decided subsequent to this case, Lord Esher pointed out that the plaintiff had no contract to rely on, and so was on the same footing as the plaintiff in this case was in regard to the defendant company.

${ }^{73}$ Robertson v. Heffer, 9 T.I.R. 622 (C.A. 1893 ). A and B were rigging the market; A gave a selling order for 5,000 shares to $C$, an innocent stockbroker. $P$, a stock-jobber, finding that he could effect a sale to one $\mathrm{X}$, a broker, who it transpired was buying for $\mathrm{B}$, purchased from $\mathrm{C}$. $\mathrm{X}$ became insolvent and unable to complete the transaction with $\mathrm{P}$, who on learning the facts 
is pegged during the formation of a company with the intent of preventing the shares from suffering an undue depreciation below their actual worth, the plaintiff may not rescind his allotment contract and recover from one of the managing committee the deposits paid. ${ }^{74}$ There was, however, in the case laying down the last proposition no discussion concerning the power of the company, through its managing committee, to deal in its own stock. This point was raised in a later case. ${ }^{75}$ At common law the corporation had a very limited right to deal in its own stock, ${ }^{76}$ and in this case the company's charter had not extended that right, but expressly prohibited the company from dealing in its own shares. Nevertheless one director and a promoter entered into an agreement to rig the market, apparently for the benefit of the company. The expenses were paid by the company. The action was brought by the official liquidator against Marzetti, a director who was innocent of the whole affair. It is taken for granted that had he assented to the payment with knowledge of the facts, he would have been liable, and the only dispute was concerning the standard of care. While the Court of Appeals refused to hold him to the standards of a trustee which had been imposed by the Master of the Rolls, nevertheless it held him negligent in approving the payment of some $£ 662$ as a "promotion expense" without investigating, and it brushed aside the contention that the stockholders had ratified the action. ${ }^{77}$ The doctrine of this case was applied at an earlier date to hold not only directors, but a

brought an action to set aside and rescind the contract with $\mathrm{C}$, and applied for an interim injunction to restrain $C$, and the London Bank which had loaned A money on the faith of P's purchase contract with $\mathrm{C}$, from enforcing the contract. The Court of Appeal dissolved the injunction unless $\mathrm{P}$ would give security to the Bank, and intimated that the Bank at the trial would be in the same position in regard to its claim as if $\mathrm{C}$ had obtained the money on the Exchange from $P$ and had handed it to the Bank, instead of P's contract of purchase. P's contention was that the Bank took the assignment of the purchase contract subject to the equities which $P$ had against $A$, the real seller. But the dictum reaches a fair result. By the rules of the Exchange $P$ and $C$ contracted as principals, and where $C$ is innocent, on strict legal principles $P$ should not be allowed to rescind. And since the Bank is innocent too it should not be enjoined from any non-legal attempts to get $\mathrm{C}$ to enforce the purchase contract.

${ }_{74}$ Landon v. Beiorley, to L.T.R. (N.S.) 505 (1848).

75 Re Railway and General Light Improvement Co.; Marzetti's Case, 42 L.T.R. (N.S.) 206 (1880).

${ }^{7}$ See Wormser, Power of a Corporation To Acquire Its Own Stock, 24 Yale L. Jour. 177 (IgI5).

77 "But it cannot be said that the company ratified the payment by passing it unquestioned on the balance sheet, unless it appeared there in such a way as to attract the attention of persons of ordinary care. There must have been direct notice, or sufficient to put a person of ordinary care upon inquiry as to the item. The mere statements on the balance sheet in this case would not have put such a person upon inquiry so as to lead him to the facts. Therefore I think there is no evidence of ratification." Brett, L. J., 42 L.T.R. (N.S.) 206, 209 (I880). 
third person. The $\mathrm{I}$ Co. was formed to purchase the business of a Paris concern. It became necessary to secure an allotment of 40,000 shares with $£_{200,000}$ paid upon them. To effect this the A Co. controlled by certain of the promoters of the $I$ Co. subscribed for that number of shares and in order to make the requisite payment gave to the National Bank its bills for discount totaling $£_{230,000}$; these were guaranteed by the L Co., it agreeing with the Bank that as the A Co. made payment to the $\mathrm{L}$ Co., such payments would be kept on deposit with the Bank until the A Co's. bills had been paid. To procure a settling-day on the stock exchange, the bank certified that the $£_{23} 0,000$ had been deposited with it in payment of shares. The $L$ Co. was prohibited from purchasing its own shares by its articles of association. After a winding-up order, a shareholder in the $\mathrm{L}$ Co., who was subject to contributions for payments of indebtedness of the company, brought a stockholders' bill against the directors and the Bank. Vice-Chancellor Malins assumed that the $£_{230,000}$ became the money of the I Co., apparently on the theory that the Bank would be estopped to deny the fact represented by it, that the directors of the $\mathrm{L}$ Co. had acted ultra vires in applying the funds in repaying the money so advanced by the Bank, and that the Bank having been participators in the breach of trust, must refund the amount. ${ }^{78}$ A later case ${ }^{79}$ identical with the earlier one, save that a settling day was never granted, refused to hold the Bank on the theory that the shareholders had not been injured by the scheme which had miscarried. ${ }^{80}$ It was on this ground that the court chiefly relied to distinguish the cases. "There can be little doubt that the result of the settling day being granted was that many transfers of shares were carried out and new shareholders put on the register, so that in all probability the constitution of the company, as regards its individual members, was materially altered. It may well be that in that state of things - the statement of the National Bank (as to I Co.'s balance) having been so acted on as to affect the constitution of the company, and to make persons liable as contributories who would not otherwise have been so liable - the statement became binding on the National Bank, so that they could not be allowed to set up the argument that they had not really received money for Laffitte \& Co. [L Co.] for which they were accountable." It was clear that the shareholders of the new company in this last case had not been prejudiced by the abortive scheme, and the court did not wish to penalize the shareholders of the Bank for the attempted fraud of

${ }^{88}$ Gray v. Lewis, L.R. 8 Eq. 526 ( 1869 ).

79 The British and American Telegraph Co. v. The Albion Bank, L.R. 7 Ex. II9 (I872).

8o There was the further difference that the action was brought at law by the company instead of in equity by a shareholder, but this would seem to be inconsequential. 
its manager. So these two cases seem to come to this: if a bank makes a false statement which effects the listing of a company it will be held to that statement in a stockholders' suit or a suit by the company, unless the Bank can show that the only stockholders are those who were such before it made the false statement, and hence no injury has resulted.

The teaching of the English cases seems to indicate that the free and open public market concept has been recognized and acted upon in criminal cases; in civil suits between market manipulators a high standard has been set with the view to protect the public from fraudulent practices; in civil litigation between third persons and market manipulators the former have prevailed if a contract or breach of trust could be worked out, but have failed where the concepts of deceit and conspiracy were resorted to. If in the latter type of case the concept of, and the need for recognition of, a right to a free and open market had been pressed upon the court it is conceivable that a different result would have been reached. ${ }^{8 \mathrm{r}}$

\section{AMERTCAN CASES}

We shall be interested in criminal cases only in so far as they bear upon the free and open market concept. In New York, wherein are located the chief security markets, ${ }^{82}$ a conspiracy similar to the De Berenger combination, ${ }^{83}$ and the manipulation of security prices by fictitious transactions ${ }^{8_{4}}$

${ }^{8 x}$ But it should be recognized that the language of Vice-Chancellor Malins in Barry v. Croskey, 2 J. \& H. I, 7o Eng. Rep. 9-I5 (186I) adopted by Lord Cairns (in Peek v. Gurney, L.R. 6 H.L. 377 (r873) and quoted with approval by Lord Justice Fry (in Salaman v. Warner, 64 L.T.R. (N.S.) 598 (Q.B. $r 89 \mathrm{r}$ ) is to the effect that the injury to such third persons is too remote.

${ }^{82}$ New York Stock Exchange, the big board, and the New York Curb. Stocks are also traded in on the New York Produce Exchange.

${ }^{83}$ People v. Goslin, 67 App. Div. I6, 73 N.Y. Supp. 520 (rst Dept. rgor), affd. in memo opinion I7I N.Y. 627,63 N.E. Ir20 (Ig02).

${ }_{4}$ People v. Farson, 244 N.X. $4{ }_{3}^{\mathrm{r}}, \mathrm{r}_{55}$ N.E. 724 (I927). For proceedings in the lower court see I23 Misc. 35I, 205 N.Y. Supp. 855 (Gen. Sess. r924). There was an intimation in the latter opinion that one engaging in fictitious security transactions knowing that quotations would be published in the newspapers could be prosecuted under $\S 95^{I}$ of the N.Y. Penal Code (New York Cahill's Consolidated Law [I930] c. 4I $\$ 95$ I) making it a felony to report or publish fictitious transactions in securities. People v. Foster, 220 App. Div. 462, 221 N.Y. Supp. 545 (Ist Dept. I927) (two judges dissenting) is a holding to the contrary on that proposition.

$\S 953$ of the New York Penal Code does not seem broad enough to cover operations by a pool which makes actual purchases and sales, though the intent is to give a fictitious price to a security.

$\S 952$ penalizes the making of a false statement or advertisement as to securities; and $\$ 954$ condemns trading by brokers against customers' orders. For cases under the latter section see People v. Ruskay, 243 N.Y. 58, I52 N. E. 464 (I926); People v. MacMasters, 246 N.Y. 592, 159 N.E. $66_{4}$ (1927); People v. Hardos, 215 App. Div. 7 I0, 212 N.Y. Supp. 892 (Ist Dept. I925), affd. without opinion, 243 N.Y. 584 , I54 N.E. $61_{5}$ (1926). 
has been punished. ${ }^{85}$ For sometime the federal statutes which make it a crime to use the mails to defraud, ${ }^{86}$ or conspire to commit an offense against the United States ${ }^{87}$ have been utilized in punishing fraudulent sales of securities, ${ }^{88}$ and recently have been effectively turned against market manipulation.

${ }^{85}$ In addition to New York, the following states, wherein are situated the indicated exchanges, have statutes which cover in some degree the field covered by the New York penal statutes.

California: (Los Angeles Stock Exchange, San Francisco Stock Exchange). Deering, Penal Code of California (193I), §395 makes it a misdemeanor to make or publish a false rumor or statement with intent to affect the market price; $\S 654 \mathrm{a}$, amended by c. 952 , Laws of 1933 , prohibits false advertising.

Illinois: (Chicago Board of Trade, Chicago Curb Exchange, Chicago Stock Exchange). Smith-Hurd, Tll. Rev. Stats. (I933), c. 38, \$ 249 prohibits fraudulent advertising.

Louisiana: (New Orleans Stock Exchange). Dart, La. Code of Cr. Procedure (I932), $\S 966$ prohibits dishonest or misleading advertising.

Massachusetts: (Boston Curb Exchange, Boston Stock Exchange). Ann. Laws of Mass. (rg2r), pt. IV, Criminal Law, c. $266, \S 9 \mathrm{r}$, prohibits untrue and misleading advertisements; $\S 92$ prohibits publishing of false or exaggerated statements.

Michigan: (Detroit Stock Exchange). Comp. Laws of Mich. (I929), § I6g9o condemns false and deceptive advertising.

Missouri: (Board of Trade of Kansas City, Mo., St. Louis Stock Exchange). Mo. Stats. Ann. (I932), TV, § 4308, misleading or deceptive advertising made a misdemeanor.

Ohio: (Cincinnati Stock Exchange). Page, Ann. Ohio General Code (I926), § I3193-2 prohibits fraudulent advertising; $\S$ I3ro8-3 prohibits reporting false transactions; $\$$ I3108-4 prohibits false statements of value of stocks or of the financial condition of a company; \& r 3 ro8-5 prohibits delivering a false note of purchase or sale by broker or employee.

Pennsylvania: (Philadelphia Stock Exchange, Pittsburgh Stock Exchange). Purdon, I8 Penna. Stats. Ann. (I930) (Vol. x8), \$§ 2321, 2324 prohibit false and misleading advertising; $\$ 245^{I}$ on criminal conspiracy is broad enough to cover fictitious stock juggling.

District of Columbia: (Washington Stock Exchange). Code of Dist. of Col. (Ig29), $\S 265$ prohibits fraudulent advertising.

No account is taken of statutes relative to gambling in stocks (see note, 45 Harv. L. Rev. 9I2 (I932); nor of state blue sky laws; nor of the Federal Securities Act. The gambling statutes would not seem to affect normal transactions on legitimate exchanges; and security acts are designed to regulate the flotation of securities, rather than the manipulation of the markets.

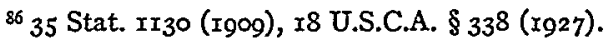

${ }^{87} 35$ Stat. 1096 (rgog), 18 U.S.C.A. $\$ 88$ ( (927) $^{8}$.

${ }^{88}$ Pandolfo v. U.S., 286 Fed. 8 (C.C.A. $7^{\text {th }}$ x922), cert. den. 26I U.S. 62I (r923). Defendant used the mails, falsely advertising concerning the plan of organization of the Pan Motor Co., assets, resources, business progress, good will, and financial standing; procured touting and circulated the articles as though written and published by disinterested parties. This case is representative of an all too frequent type of promotion which can be punished if there is an attempt to use the mails. The fact that the defendants entertained the confident hope of ultimately bringing the enterprise to a state where all investments therein would prove profitable is unavailing, Moore v. U.S., 2 F.(2d) 839 (C.C.A. $7^{\text {th }}$ I924), cert. den. 267 U.S. 599 (I925). The indictment need not allege that the stock was lacking in value to such an extent as to defraud those who paid the price. Kellogg v. U.S., I26 Fed. 323 (C.C.A. 2 d I903); U.S. v. Palmieri, I69 Fed. 490 (C.C.S.D. N.Y. I909); a contra holding by the 7 th Circuit in Miller v. 
In Harris v. U.S., ${ }^{89}$ the Circuit Court of Appeals for the ninth circuit affirmed a conviction under an indictment the gist of which was a manipulation of stock prices on the San Francisco and Spokane Stock Exchanges, the circulation of reports of these false transactions, and a scheme to hold up delivery of stock sold so that it would not come on the market at the manipulated prices. A similar situation was presented in U.S. v. Brow ${ }^{90}$ with a similar result. Judge Woolsey, in the latter case, referred to the effect of the pool operations as the creation of "a kind of price mirage which may lure an outsider into the market to his damage."9r His theory is that the public is entitled to rely upon the quoted price as representing the "true chancering of the market" effected by "a series of actual sales between various persons dealing at arm's length in a free and open market." ${ }^{2}$ After dealing at length with Scott v. Brown ${ }^{93}$ and the case of Sanderson and Levi, ${ }^{94}$ he comments:

It seems to me that the teaching of these cases is that, where two or more persons engaged in a so-called pool operation on a stock exchange in respect of a stock, it is only by scrupulously maintained honesty of dealing, such as the court found to be the fact in the Sanderson and Levi case, that they may escape condemnation as a fraudulent conspiracy. The slightest step over the line of absolute fair dealing takes them into a zone of condemnation by the courts, and the doctrine applicable to each member of the pool is the new maxim-caveat venditor. 95

In both of those cases, it will be remembered, there were actual purchases with no resort to wash sales or touting. In the Sanderson and Levi case where the court found the price to be fair the pool operations were sustained; in the other where the price was found to be unfair they were roundly condemned. So it would seem that the reasoning of this case condemns any and all pool operations which effect a price a court using hindsight will conclude was not a fair one. The seller, indeed, must beware if he sees fit to enter into a combination.

U.S., I74 Fed. 35 (C.C.A. 7 th I909) was explained by the same circuit, in Moore v. U.S., stipra, to be due to the form of the statute then prevailing, so there is no conflict now between these circuits. And the statute has been given a liberal construction. See Noyes, J., in Wilson v. U.S., Igo Fed. 427,433 (C.C.A. 2d rgIr).

${ }^{89} 48$ F. (2d) 77 I (C.C.A. gth I93I).

${ }^{90} 5$ F. Supp. 8I (D.C.S.D. N.Y. I933), noted in 34 Col. I. Rev. 500 (r934); 82 Univ. Pa. L. Rev. 54I (r934). Indictment charged defendants with running a pool in Manhattan Electric to artificially raise the price without regard to the real value to let them unload; that wash sales and touting were used. A demurrer was overruled.

${ }^{92} 5$ F. Supp. 8I, 93 (D.C.S.D. N.Y. 1933).

${ }^{92} 5$ F. Supp. $8 \mathrm{r}, 85$ (D.C.S.D. N.Y. I933).

${ }^{23}$ Supra note 56.

94 Supra note 57 .

95 Supra note go (italics ours). 
Exchanges have the opportunity and the power to assist in raising the standards of trading. They may enact such by-laws and rules as the members deem advisable, subject of course to the general restriction that they be not contrary to law or to public policy, and, if the exchange is incorporated, that they be within the charter. ${ }^{96}$ And where members have been suspended or expelled, the courts have refused to disturb the action of the exchange, where it had jurisdiction of the subject-matter and of the alleged offender, proceeded regularly under the rules provided for its guidance, and there was evidence to support its decision. ${ }^{97}$

The question for the court is not whether, passing upon the evidence as res nova, it would have reached the same conclusion as that of the board of managers, or whether the conclusion was reasonable or unreasonable, but simply and wholly whether the case was so bare of evidence to sustain the decision that no honest mind could reach the conclusion that the relator's conduct was "inconsistent with just and equitable principles of trade." 98

And the burden of showing lack of evidence is upon the one who assails the decision. ${ }^{99}$ With such power of an exchange in mind it is interesting to note a step recently taken by the New York Stock Exchange. By rule adopted Feb. I3, I934 it prohibits members from directly or indirectly participating in, having an interest in the profits of, or knowingly managing or financing a manipulative operation. It defines a manipulative operation as any pool or joint account, whether in corporate form or otherwise, organized or used intentionally for the purpose of unfairly influencing the market price of any security by means of options or otherwise and for the purpose of making a profit thereby. ${ }^{\mathbf{x} 0}$ It seems to have adopted the

${ }^{56}$ Meyer, The Law of Stock Brokers and Stock Exchanges (I93I), 79-86.

97 People ex rel. Johnson v. N.Y. Produce Exchange, I49 N.Y. 40r, 44 N.E. 84 (I896) (expulsion of member for fraudulent breach of contract sustained); in re Haebler v. N.Y. Produce Exchange, $x_{49}$ N.Y. 4I4, 44 N.E. 87 (I896) (similar case and similar result); Belton v. Hatch, I09 N.Y. 593, I7 N.E. 225 (I888) (expulsion of member for doing business in a reckless and unbusinesslike manner sustained); Young v. Eames, 78 App. Div. 229, 79 N.Y. Supp. ro68 (xst Dept. I903), affd. I8I N.Y. 542, 73 N.E. Ir34 (rgo5) without opinion (expulsion of member for trading against customer's order sustained).

${ }_{98}^{8}$ Andrews, Ch. J., in People ex rel. Johnson v. N.Y. Produce Exchange, note 97, at p. 4r4.

99 Young v. Eames, supra note 97.

${ }^{300}$ Rules of the New York Stock Exchange, c. XIV, § I5. An earlier rule adopted Aug. 2, I933, c. XV, $\S 6$ merely required members to report their interest in pool operations; the Committee on Business Conduct could then disapprove.

Art. XVII, $\S 4$ of the Constitution of the New York Stock Exchange subjects a member to disciplinary proceedings for purchasing or selling for the purpose of upsetting the equilibrium of the market and bringing about a condition of demoralization in which prices will not fairly reflect market values.

Just prior to the rule of Aug. 2, I933 a pool was run in American Commercial Alcohol in which the'Exchange seems to have been deceived. An inactive stock selling around $\$ 6$ in Feb., 
rationale of U.S. v. Browm, ${ }^{\text {xox }}$ and placed upon the shoulders of its administrative authorities the burden of determining whether this is to be all or nothing in the way of wise regulation. Too much, however, should not be expected from the Exchange itself, because of its limited control over nonmembers. Steps taken along another line, seemingly for the interest of the public, have been thwarted by non-members. ${ }^{102}$

Where a contest has arisen between market manipulators, a certain divergence from the English law is to be noted. In the extreme case of the corner, the contract between the manipulators has been held to be illegal and unenforceable, ${ }^{x 03}$ and also where the contract was to effect fictitious transactions. ${ }^{104}$ And for reasons of public policy a contract for touting is not actionable. ${ }^{105}$ With $S c o t t v$. Brovon $^{\text {106 }}$ in mind, it seems fairly clear that the English courts would have reached the same results thus far. But where the contract or the pool operations have not involved any of the foregoing elements American courts, unlike the English court in the Scott v. Brown case, have not raised the matter of illegality. ${ }^{107}$ And where

I932 was raised to a peak of $\$ 89 \frac{7}{8}$ on July 18 , $x 933$ and subsided to around $\$ 30$ after the pool got out. One operator made around $\$ 138,000$ between May and July, I933, besides brokerage fees of approximately $\$ 2.50$ for each 100 shares sold. Vol. 78, Cong. Rec. 8406-8410 (r934).

ror Supra note go.

${ }^{202}$ Pirnie Simons \& Co. v. Whitney, I44 Misc. 8I2, 259 N.Y. Supp. 193 (I932), noted in 32 Col. L. Rev. I253 (I932), and discussed infra pp. 74-75.

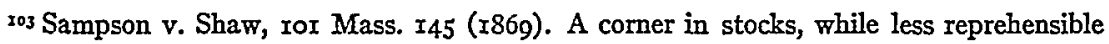
than a corner in necessities of life, involves the same type of action: a purchase of more than the available supply with the intent to force a settlement from the shorts at the purchaser's figure; and the legal principles which condemn the one should condemn the other. The destruction of the liquidity of the market early led the New York Stock Exchange to set up provisions whereby corners could be broken. Constitution of the N.Y. Stock Exchange, art. III, $\S 7$. For cases holding corners in commodities illegal see In re Chandler, Fed. Cas. No. 2, 590 (D.C. N.D. Ill. I874); Lane v. Leiter, 237 Fed. I49 (C.C.A. 7 th I9I6); Foss v. Cummings, 149 Ill. 353, 36 N.E. 553 (1894); Raymond v. Leavitt, 46 Mich. 447,9 N.W. 525 (I88I). In the Lane and Foss cases the court could rely on a state statute, but in each case the court denounced the corner as void at common law.

${ }^{204}$ Livermore v. Bushnell, 5 Hun. (N.Y.) 285 (Ist Dept. I875).

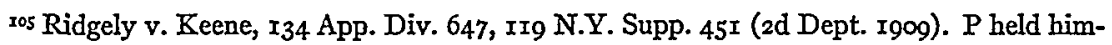
self out to his clientèle as an impartial, experienced financial adviser. Despite this, he entered into a contract with $D$ to bull the market for a stock in which $D$ was operating a pool. The court speaks of P's relation with his clients as one of confidence and trust, and that the law because of that relationship would not permit him to assume conflicting obligations. In view of the language, could a client have recovered damages of $P$, on the theory of a breach of trust?

${ }^{106}$ Supra note $5^{6 .}$

${ }^{207}$ Gates v. Megargel, 266 Fed. 8 II (C.C.A. 2 I I920), cert. den. 254 U.S. 639 (Ig20) (here the pool manager was made to account in a fiduciary capacity toward the syndicate members; to have held otherwise would have placed a premium on gross conduct); in re Lathrop, Has- 
the question was raised for the first time on appeal the court refused to consider the matter at length. ${ }^{108}$ Where it has been squarely raised the court in one case concluded the pool agreement to sell short was a gambling transaction and illegal, ${ }^{109}$ but allowed the plaintiff to recover his share of the profits. ${ }^{\text {II }}$ Another case ${ }^{\text {III }}$ upheld an agreement to keep stock owned by the contracting parties off the market so that it would not come in competition with treasury stock being sold by the company which they had promoted. The agreement was attacked as being a restraint both of alienation and of trade. There are many factual differences between this sort of an arrangement and pegging the market during security distribution, but the end to be attained by each is similar: an orderly course of action, designed to prevent the market from becoming unduly depressed to the injury of the company. But where the agreement did not stem from a common interest the contract was held to violate the state antitrust statute. ${ }^{\mathrm{Ix} 2}$

The American cases involving litigation between third persons and market manipulators are perhaps more interesting for suggested lines of attack than for results reached. An early lower New York court case ${ }^{\mathrm{Ir} 3}$ denied recovery in an action of deceit to a purchaser who had relied on the market quotation, falsely effected by the defendant through wash sales. ${ }^{\text {Ir }}$

kins \& Co., 216 Fed. IO2 (C.C.A. $2 \mathrm{~d}$ r9r4), appeal dismissed for want of jurisdiction sub nom. Hotchkiss v. Ernest, 235 U.S. 684 (r914) (the notorious Hocking Pool was involved); Marston v. Gould, 69 N.Y. 220 (1877); Ridgely v. Taylor \& Co., I07 App. Div. 265, 94 N.Y. Supp. ro89 (Dept. 1905), I18 App. Div. Io, I03 N.Y. Supp. 262 (2d Dept. r907), x26 App. Div. 303, I 10 N.Y. Supp. 665 (2d Dept. Igo8); Burleigh v. Bevin, 22 Mis:. 38, 48 N.Y. Supp. I20 (Sup. Ct. 1897); Boody v. Drew, 2 T. \& C. 69 (N.Y. Supp. Ct., Ist Dept. 1873); McMillan v. Whitley, 38 Utah 452, II3 Pac. I026 (I9rI).

${ }^{108}$ Quincey v. White, 63 N.Y. 370 (1875).

${ }^{109}$ Defendant, manager of the venture, sold the shares short through his broker in New York. If this were done on a legitimate exchange, it would szem that there was a valid contract. Chicago Board of Trade v. Christie Grain \& Stock Co., I98 U.S. 236 (Ig05); U.S. v. N.Y. Coffee \& Sugar Exchange, Inc., 263 U.S. 6II (I924); Winslow v. Kaiser, 3I3 Pa. 577, I 70 Atl. I35 (I934); Meyer, The Law of Stock Brokers and Stock Exchanges (I93I), 216-23I; but cf. Weld v. Postal Telegraph-Cable Co., I99 N.Y. 88, 92 N.E. 415 (I9I0); note, 45 Harv. L. Rev. 9 I2 (I932).

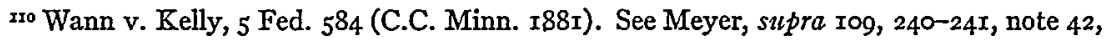
to the effect that a pool as such is not illegal.

${ }^{2 r x}$ Williams v. Montgomery, I48 N.Y. $5^{x g}, 43$ N.E. 57 ( $\left.x 896\right)$.

rz Pound v. Lawrence, 233 S.W. 359 (Tex. Civ. App. I921).

${ }^{113}$ McGlynn v. Seymour, I4 Daly 420 (N.Y. Com. Pl. I888); contra dictum in Brown v. Werblin, I38 Misc. 29, 244 N.Y. Supp. 209 (Sup. Ct. 1930).

${ }^{14} 4$ "A wash sale is at most an affirmation that the buyer is paying a certain price for a certain lot of stock. ... . They [wash sales] are at most false affirmations of an opinion as to value." McGlynn v. Seymour, I4 Daly (N.Y.) 420, 422, 423 (Com. PI. I888). 
But the reasoning, not the decision, has been overruled by the Court of Appeals of New York which has held that an affirmation of price paid is one of fact and not opinion. ${ }^{1 x 5}$ Had the court in the first case placed its decision on the ground that the injury from the wash sales was too remote, it would have been on firmer ground. ${ }^{\text {Ir6 }}$ But in a somewhat analogous situation recovery has been allowed. Defendant, owner of a leasehold interest about to be forfeited for rent past due, conveyed to $\mathrm{X}$ for a consideration stated in the deed to be $\$ 100,000 ; \mathrm{X}$ conveyed to $\mathrm{M}$, the deed also reciting a consideration of $\$ 100,000$. $M$ then gave a trust deed to a title and trust company to secure the issue of $\$ 75,000$ of notes. The transactions between $D, X$, and $M$ were wholly fictitious. There was one other element of fraud: the trust deed was drawn in such a manner that it appeared to be made upon the entire premises instead of merely on the leasehold. Plaintiff seeing the abstract of title was led to believe that $\$ 100,000$ had been the recent purchase price and that $M$ had paid $\$ 25,000$ thereon. Thereupon she purchased $\$ 4,000$ of the issued notes to her damage. It was held that the complaint stated a cause of action in deceit. ${ }^{\text {II }}$ The misleading nature of the trust deed prevents the case from being a square authority for the proposition that third persons generally may rely on prices which are quoted for them to rely upon, and recover if damage is sustained. But even if the action of deceit for wash sales is allowed, probably it does not afford protection to the great bulk of purchasers where such fictitious transactions are used only intermittently-to spur up the market when it lags; for although the end sought may be thus attained by the manipulators, yet the last quotations upon which purchasers relied may have been genuine. Protection here would be afforded only by the recognition of the free and open market concept which would afford recovery if the wash sales were a substantial factor in producing the artificial price. A case which has probably gone as far as any common law case in recognizing this concept is McElroy v. Harnack. ${ }^{118}$ The defendant brokers with

${ }^{275}$ Fairchild v. McMahon, 139 N.Y. 290, 34 N.E. 779 (I893); Miller v. Barber, 66 N.Y. $55^{8}$ (1876); accord Thompson v. Koewing, 79 N.J.L. 246, 75 Atl. 752 (I9ro).

${ }^{n 6}$ See the statement of Lord Hatherely concerning the false rumors of De Berenger, supra p. 6r.

${ }^{127}$ Leonard v. Springer, I97 Ill. 532, 64 N.E. 299 (Ig02).

${ }_{\text {II8 }}^{213}$ Pa. 444, 63 Atl. I27 (Igo6). The open market concept seems to have been recognized in Singleton v. Harriman, 272 N.Y. Supp. 905 (Sup. Ct. 1933) when P was permitted recovery of damages sustained in purchasing stock upon representations concerning bid and asked prices. Instead of a bona fide market for the stock the price was artificially maintained and known so to be by defendants. On the measure of damages see Hotaling v. A.B. Leach \& Co., Inc., 247 N.Y. 84 , I59 N.E. 870 , 57 A.L.R. II36 (I928). 
one of the other defendants organized a corporation, issued bonds of the company in an amount thirty times the value of its property, and the brokers by fictitious and a few actual sales on the stock exchange gave the bonds a high market value, and thus enabled the other two defendants to borrow money from the plaintiff, with the bonds as collateral. It was held that the brokers were liable to the plaintiff for the loss occasioned by the inflated collateral in an action of trespass for conspiracy. Since conspiracy of and in itself did not give rise to a cause of action at common law, ${ }^{\mathrm{Ix}}$ the case would seem to be a recognition of the right to a free and open market, which may be invoked by anyone injured by its invasion. A subsequent case in the same state would seem to qualify this, however, to the extent that a combination of two or more persons must be proved to maintain the action. ${ }^{220}$

Rescission is a possibility, of course, if the purchaser can show that his vendor has rigged the market, but a case involving a vendee who knew that his vendor was so engaged denied relief. ${ }^{22}$ And the profits of a pool have been held not a trust fund for injured purchasers in an action brought by an individual. ${ }^{122}$

As the pool in the last case operated in New York, an interesting question would have arisen had the Attorney-General brought the action under the Martin Act ${ }^{\mathrm{T} 23}$ asking for a receiver for the pool profits and such other property, if any, with which they had been commingled for the benefit of all intervening persons who could show injury. No sound reason is perceived why this could not be done. The Court of Appeals has termed the statute remedial, and said that "In a broad sense the term (fraud) includes all deceitful practices contrary to the plain rules of common hon-

II9 Supra note 69.

${ }^{\text {I20 }}$ Ballantine v. Cummings, $220 \mathrm{~Pa}$. 62I, $70 \mathrm{Atl} .546$ (Ig08) (failure to prove the unlawful combination defeats the right to recover in an action of conspiracy); but cf. Van Gilder v. Bower, 314 Pa. 327, 330, I7I Atl. 600 (I934).

rax In re B. Solomon \& Co., 268 Fed. 108 (C.C.A. $2 d$ I920).

${ }_{222}$ Brown v. Werblin, I38 Misc. 29, 244 N.Y. Supp. 209 (Sup. Ct. I930). Plaintiff alleged that defendants formed a pool in Advance-Rumely stock, used wash sales and tipsters' sheets; that in reliance upon such false information she and many others were injured, and that she brings her action in her own behalf and in behalf of others similarly situated. The court dismissed the action, stating that plaintiff had an adequate remedy at law; that there was no trust relationship between plaintiff and the pool operators; that there was no community of right or interest in the subject-matter of the action permitting plaintiff to bring a representative suit.

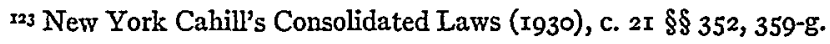


esty." ${ }_{124}$ In People v. Rice ${ }^{\mathrm{x} 25}$ an action by the Attorney-General restraining the defendant from engaging in rigging the market was sustained. Receivers have been appointed of property acquired from the sale of securities effected by false representations, ${ }^{\mathrm{x} 26}$ and by a brokerage firm after becoming insolvent. ${ }^{127}$ So the natural conclusion would seem to be that a receiver could be appointed of the profits resulting from a pool which was charged with the same sort of deceitful practices engaged in by Rice. And if the New York courts should entertain the same opinion toward pool operations as entertained by Judge Woolsey in U.S. v. Brozen, ${ }^{\text {,28 }}$ it would seem that if the price effected or about to be effected by the pool was or would be unfair, the pool could be enjoined from operating and a receiver appointed of any property accruing from such operations.

Another line of attack suggested by cases would be a suit against pool operators under the state or federal anti-trust statutes, whichever might be applicable to the situation. Both American and English law have set up freedom of competition as the governing standard in business, but have employed opposite methods to effect that goal. ${ }^{\text {I29 }}$ The English law in general has relied upon freedom of action to effect the desideratum, ${ }^{130}$ but beginning in 1887 with the Kansas statute forbidding monopolies in grain,

${ }_{24}$ People v. Federated Radio Corporation, 244 N.Y. $33,37,1_{54}$ N.E. 655 (r926) scienter is not an element of the "fraud" which the statute was aimed at. To the same effect on the matter of scienter see People v. Ruocco, I37 Misc. 400, 242 N.Y. Supp. 4I (I930); People v. Latta, I37 Misc. 208, 244 N.Y. Supp. 487 (1930).

"The statute is remedial in its nature, and was passed to protect the inexperienced, confiding and credulous investor, and save him from bis own foolish cupidity. It should, therefore, be liberally and sympathetically construed in order that its beneficent purpose may, so far as possible, be attained." Edgcomb, J., in People v. F. H. Smith Co., 230 App. Div. 268, 269, 243 N.Y. Supp. 446 ( (930). $^{2}$

${ }_{225} 221$ App. Div. 443, 223 N.Y. Supp. 566 (1st Dept. I927). Acquiring an option on stock at rof a share, the defendant touted it in a supposedly impartial financial magazine edited by himself, washed the stock on the Boston Curb, and disposed of it at prices ranging from $5 \circ \mathrm{c}$ to $9 \circ$ per share. The opinion does not discuss the matter of a receiver.

For an action under the New Jersey Blue Sky Law where the defendants operated similarly to Rice see Stevens v. Wallace, ro6 N.J. Eq. 352, r5o Atl. 835 (1930). Defendants were enjoined and a receiver appointed. The court summarily dismissed the objection that no persons residing within New Jersey had been wronged, and refused to even consider the contention that the act was unconstitutional.

${ }_{226}$ People v. Royal Development Co., 239 App. Div. 518, 268 N.Y. Supp. 98 (4th Dept. 1933).

${ }_{\text {r27 }}$ Cruse, as Receiver v. Rounds, 235 App. Div. 894, $25^{8}$ N.Y. Supp. 387 (4th Dept. r932).

${ }^{128}$ Supra note go.

229 Cf. on almost identical facts Thomsen v. Cayser, 243 U.S. 66 (I9I7) with Mogul Steamship Co., Ltd. v. McGregor, Gow \& Co., [1892] A.C. 25 .

${ }^{130}$ The Anti-Trust Law of the British Commonwealth of Nations, 32 Col. L. Rev. 324 (I932). 
state anti-trust legislation has been piling up until only a few states remain without laws relating to monopolies and restraints of competition or trade. ${ }^{13 x}$ Some states have taken the Sherman Act $^{132}$ as a model, while others single out particular industrial or agricultural products for special protection; and the penalties or relief afforded to injured third parties are as varied in character as the statutes. ${ }^{133}$ For our purposes it will suffice to note that the language of the New York anti-trust act is extremely broad, ${ }^{\mathrm{r} 34}$ and that third parties may seek redress against those violating the statute. ${ }^{35}$ And it has been recently invoked by a third person to nullify a resolution of the New York Stock Exchange which sought to fix a maximum charge for brokerage services in connection with the retailing of securities in packages. ${ }^{x 6}$ The facts were these: The plaintiff bought blocks of securities through members of the exchange, and then arranged and retailed them in packages containing one share of twenty-five or fifty different stocks; the price charged was based on the closing market asked price, plus a brokerage charge figured on the basis of buying the stocks in odd lots, which the plaintiff's circulars tended to conceal, although this could have been discovered by reference to the daily newspaper quotations. Some of the packages contained a few high priced stocks, but all contained a great number of low priced speculative stocks. After an investigation of this and similar plans the Exchange passed a resolution forbidding its members to furnish securities in connection with such schemes.

I3x A Collection and Survey of State Anti-Trust Laws, 32 Col. L. Rev. 347 (1932).

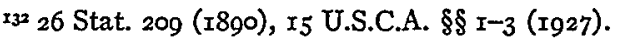

${ }^{333}$ Supra note $13 \mathrm{r}$.

${ }^{234}$ New York Cahill's Consolidated Laws (1930), c. 2 I, $\S 340$. In People v. Epstean, Io2 Misc. 476, I70 N.Y. Supp. 68 (Sup. Ct. xgr8), affd. x90 App. Div. 899, I79 N.Y. Supp. 941 (Ist Dept. I9I9), photo-engravings were held outside the scope of the act then in effect because not a "commodity of common use." The law was amended to include "any article or product" used in the "conduct of trade, commerce, or manufacturing," and photo-engravings are now within the statutory ban. Standard Engraving Co. v. Voltz, 200 App. Div. 758, r93 N.Y. Supp. 93 I (Ist Dept. I922). And a completed building foundation has been regarded as a commodity within the act. People v. Amanna, 203 App. Div. 548, I96 N.Y. Supp. 606 (Ist Dept. x922).

${ }^{135}$ Straus v. American Publishers' Association, 177 N.Y. 473, 69 N.E. II07 (1904) (allowing an action of injunction and damages against a combination of book publishers fixing price as to uncopyrighted, but not as to copyrighted books; for subsequent phases of this litigation see I93 N.Y. 496, 86 N.E. 525 (Iģ08), I99 N.Y. 548, 93 N.E. II33 (IgII) reversed in 23I U.S. 222, 34 Sup. Ct. 84 (I9r3) on the ground that the agreement as to copyrighted books was within the denunciation of the Sherman Act); Gerseta Corporation v. Silk Association of America, 220 App. Div. 302 (Ist Dept. I927) (action for damages for wrongful expulsion from defendant association and resultant boycott); Rourke v. Elk Drug Co., 75 App. Div, 145, 77 N.Y. Supp. 373 (1902) (action for damages for trade libel, intimidation, and business interference).

${ }^{\text {r36 }}$ Pirnie Simons \& Co. v. Whitney, I44 Misc. 8I2, 259 N.Y. Supp. I93 (I932), noted in 32 Col. I. Rev. I253 (1932). 
Its stated objection was that grave abuses had arisen in the fixed investment trusts, one of which was an excessive charge for services rendered; that these so-called unit or group plans were, in many instances, similar to the fixed trusts and subject to the same abuses. For instance, in the case of low priced shares the plaintiff's service charge was so high that the purchaser would suffer a loss unless there was an increase of more than 80 per cent in the market price: the plaintiff's No. I package, the largest selling portfolio, containing twenty-five nonpaying dividend stocks, was being sold to the public at a charge of some $\$ 42$ over the quoted market price of approximately \$100. And the scheme was unusually wasteful both from the standpoint of the purchaser and the corporations of which he became a shareholder. ${ }^{137}$ The resolution did, however, permit connection with any plans which substantially corresponded to one outlined by the Exchange, the features of which offered diversification, eliminated undue speculation and economic waste, and reduced the service charge to the purchaser to a maximum of ten per cent. If we concede the plaintiff's contention that its unit plan distributed stock so widely that manipulation and short selling would be made more difficult, and that the Exchange's motive was to protect its odd lot members, the fact remains that the resolution afforded protection to the public against predatory practices and was economically expedient. ${ }^{x{ }^{8}}$ If this type of indirect price-fixing may be attacked under the New York anti-trust law why may not the more direct price-fixing of pool operations be attacked?

An interesting outgrowth of the resolution taken by the Exchange is a - suit in federal court against it and its governing committee for treble damages under the Sherman Act. ${ }^{139}$ And this suggests that pool manipulation effected by a combination might be subject to attack under the federal anti-trust statutes. Any pool, speculative, stabilization or distribu-

${ }_{337}$ If the holder of a single certificate should die the cost of securing the necessary approval of tax authorities to the transfer of the certificate, costs of filing a certified copy of the will and proof of appointment of executors or administrators with the transfer agent would far exceed the value of a low-priced stock - the type of stock which predominated in all of plaintiff's portfolios. And the cost to a corporation for issuing a certificate, in excess of 50 \&, was obviously economically unsound where the stock was selling around \$I or \$2. Expense of making dividend payments and giving notices of stockholders' meetings would also be greatly enhanced if there were many unit shareholders.

${ }^{x} 3^{8}$ The court's animus in the Pirnie Simons \& Co. case toward price-fixing may be deduced by a comparison of that case with Heim v. N.Y. Stock Exchange, 64 Misc. 529, Ir8 N.Y. Supp. 59 I (Sup. Ct. I909), affd. I38 App. Div. 96, I22 N.Y. Supp. 872 (2d Dept. I9ro) in which an attack against a non-intercourse resolution failed. $\$ 444$, N.Y. Penal Law (the first of the sections numbered 444) now prohibits the type of action sustained in the Heim Case.

${ }^{339}$ Pirnie Simons \& Co. v. New York Stock Exchange, N.Y.L.J., Jan. II, I933 (S.D.N.Y. I932) (point discussed there was solely a procedural one). 
tion, will, during the period of its activity thwart the operation of a free market; its members do not compete against each other, and by their combined financial strength are able to make quantity purchases or sales designed to affect price, which a single member could not make. Pricefixing is the aim of any pool, and to the degree that it is successful (and even though it is eventually a failure, prices are disaligned and affected during the period of operation) the price, which affects every purchaser or seller who has occasion to resort to the only market where he can buy or sell, is one established by combination and not competition. The selling and buying by the pool, it is true, are effected by transactions normally intrastate. But if a court is willing to recognize that securities move to and from a national market, such as New York, as buyers and sellers throughout the country desire to purchase or sell, ${ }^{140}$ there is an involuntary restraint imposed by pool operators upon interstate commerce within the meaning of the federal anti-trust statutes. ${ }^{x 4 x}$

If this position were taken it is barely possible to sustain a stabilization or distribution pool under the rule of reason ${ }^{\mathrm{r} 2}$ if the fixed price is fair, because the end sought is orderly marketing. In Board of Trade of Chicago v. U.S., ${ }^{x 3}$ the Supreme Court sustained the Board's call rule fixing the price for grain "to arrive" at the day's closing bid, which would then be effective until the opening of the next session. But here the restriction was really upon the period of competitive price-making-it required members who desired to buy grain "to arrive" to make up their minds before the close of the call (usually about 2 P.M.) as to how much they were willing to pay during the interval which would end at the next session of

${ }^{14^{\circ}}$ That securities do move in and affect interstate commerce is the underlying thesis of the Exchange Act and the Securities Act. See also Hanna, The Federal Regulation of Stock Exchanges, 5 So. Calif. L. Rev. 9 (I93I).

${ }^{24}$ U.S. v. Patten, 226 U.S. 525 (xgr3). A combination to run a corner in cotton by transactions effected wholly on the N.Y. Cotton Exchange constitutes an involuntary restraint upon interstate commerce. The defendants unsuccessfully contended that $(I)$ the conspiracy does not belong to the class in which the members are engaged in interstate trade or cammerce, and agree to suppress competition among themselves; (2) running a corner, instead of restraining competition, tends, temporarily at least, to stimulate it; and (3) the obstruction of interstate trade and commerce resulting from the operation of the conspiracy, even although a necessary result, would be so indirect as not to be a restraint in the sense of the statute.

${ }_{142}$ See Standard Oil Co. of N.J. v. U.S., 22I U.S. I (IgII) where the rule was enunciated, and Appalachian Coals, Inc. v. U.S., 288 U.S. 344 (I933) where the court evinces a determination to take a broad and comprehensive view of the underlying conditions and purposes in each case. In general for a discussion of the federal anti-trust statutes see 32 Col. L. Rev. I73, et seq. (1932), and the literature discussed and referred to therein.

I43 246 U.S. 23 I (IgI8). 
the Board (usually the following morning). ${ }^{\mathrm{r} 4}$ And in the main the Supreme Court has not been sympathetic toward price-fixing combinations. ${ }^{\text {.45 }}$

\section{THE EFFECT OF THE ACT}

Upon the law which has recognized and given protection under the concept of a free and open market the Act effects little change. Anything in excess of actual damages, it seems, could not be recovered, even if a suit against members of a pool were sustained under the federal anti-trust acts or under a state anti-trust act which permitted a recovery greater than actual injury. ${ }^{\mathrm{I} 46}$ Nor could manipulation not in contravention of the Commission's rules and regulations be attacked. One of the values of the Act, perhaps, is the clear pronouncement that exchanges are affected with a public interest ${ }^{x 47}$ and that trading upon national exchanges must be so conducted as to afford the ultimate protection to the trader, the investor, and the public generally. And if a prediction may be hazarded its effectiveness lies in investing regulatory details and supervision in the Federal Reserve Board and the Securities Exchange Commission. The Commission, also put in charge of the Securities Act, has the large opportunity and the onus of protecting the public against fraudulent issues and fraudulent manipulation.

\footnotetext{
${ }^{344}$ Attention was called by the court to the limited scope of the rule, applying only to grain "to arrive"; and that within the narrow limits of its operation the rule helped to improve market conditions. For other cases involving organized exchanges in which restraint has been sustained see Hopkins v. U.S., I 7 I U.S. 578 ( 1898 ) (brokerage rate fixed by organized exchange of commission merchants); Anderson v. U.S., I7I U.S. 604 (1898) (non-intercourse agreement by members of dealers' exchange). Similar activities by a group of dealers on the open market would seem to be condemned, for in Swift \& Co. v. U.S., I96 U.S. 375 (I905) both cases were held to their special facts. See also Moore v. N.Y. Cotton Exchange, 270 U.S. 593 (I926) and Board of Trade v. Christie, I98 U.S. 236 (1905) sustaining contracts between the exchanges and a telegraph company which permitted quotations to be furnished only to persons approved
} by the exchanges.

${ }_{45}$ U.S. v. Trenton Potteries Co., 273 U.S. 392 (1927).

U.S., supra note $\mathrm{I}_{43}$, see P. 40r).

$14^{6} \& 28(a)$.

147 See generally § 2. 